\title{
Cultura material escolar nas escolas radiofônicas de Bragança: entre permanências e inovações pedagógicas (1960-1970)
}

\section{Culture of school material in the radiophonic schools in Bragança: permanencies and pedagogical innovations (1960-1970)}

\author{
Rogerio Andrade Maciel* \\ Cesar Augusto Castro** \\ Maria do Perpétuo Socorro Gomes de Souza Avelino de França***
}

\begin{abstract}
RESUMO
O presente artigo tem por objetivo analisar a cultura material escolar nas escolas radiofônicas de Bragança e a constituição das permanências e inovações pedagógicas, no período de 1960 - 1970. Metodologicamente, utilizamos a abordagem da Nova História Cultural como análise sobre o uso dos materiais escolares e as representações de educação dos sujeitos sobre esses materiais no cotidiano das salas de aula. Foram identificados três tipos de escolas: uma que funcionava na casa da monitora; outra em um barracão de palha; e a última em uma escola municipal. A cultura material escolar, nesta instituição escolar, está constituída pelos seguintes materiais: materiais de escrita (giz e lápis com borracha); materiais de suporte de escrita (quadro negro, cartaz, cadernos e folhas de papel sem pauta); mobílias (mesas de madeiras toscas e bancos retangulares de madeiras); materiais de leitura (pequenos textos e relatórios); materiais de iluminação (lamparinas de pressão, lampiões e aladins); indumentárias dos alunos (roupas de chita
\end{abstract}

* Universidade Federal do Pará. Campus Universitário de Bragança. Bragança, Pará, Brasil. E-mail: rogeriom@ufpa.br. http://orcid.org/0000-0003-1673-5215.

** Universidade Federal do Maranhão. São Luís, Maranhão, Brasil. E-mail: ccampin.ufma@ gmail.com. http://orcid.org/0000-0001-7650-895X.

*** Universidade do Estado do Pará. Belém, Pará, Brasil. E-mail: socorroavelino@hotmail. com. http://orcid.org/0000-0002-6974-2606. 
artesanal e algodão); materiais de proteção (palhas de Inajás e Babaçu); material de comunicação e ensino (intitulado como rádio cativo). Esses materiais permitiram identificar as permanências e inovações pedagógicas. Concluiu-se que os materiais escolares produziram representações críticas, emancipatórias e evangelizadoras cuja finalidade era alfabetizar os jovens e adultos das escolas radiofônicas de Bragança, Estado do Pará.

Palavras-chave: Cultura material escolar. Escolas radiofônicas. Representações de educação. Educação de Jovens e Adultos. Bragança (PA).

\begin{abstract}
The present article aims to analyse the school material culture in radiophonic schools of Bragança and the creation of permanencies and pedagogical innovations in the period from 1960 to 1970 . We used the New Cultural History approach as the method to analyse the use of school materials and the education representations of subjects on these materials in the daily life of classrooms. Three types of schools were identified: (i) a school that operated in the house of the monitor; (ii) another in a straw shed; and (iii) one that operated on a municipal school. The school material culture, in this school institution, consists of the following materials: writing materials (chalk and pencil with eraser); materials of writing support (blackboard, poster, notebooks, and blank sheets of paper); furniture (rough wooden tables and rectangular wooden benches); reading materials (short texts and reports); lighting materials (lamps, pressure lamps, and aladins); costumes of the students (handmade chita and cotton clothing); protection materials (Inajá and Babassu thatches); material of communication and teaching (known as captive radio). These materials made it possible to identify the permanencies and pedagogical innovations. We concluded that the school materials produced critical, emancipatory, and evangelizing representations whose purpose was to alphabetize the youth and adults of the radiophonic schools in Bragança, State of Pará.
\end{abstract}

Keywords: School material culture. Radiophonic schools. Education representations. Education of youth and adults. Bragança (Pará State).

\title{
Introdução
}

A análise da cultura material escolar nas escolas radiofônicas de Bragança e a constituição das permanências e inovações pedagógicas nessas instituições de ensino no período de 1960 a 1970 trouxe à tona uma relação entre os sujeitos, 
os materiais escolares, os espaços escolares e as mais variadas práticas culturais que se constituem enquanto uma instituição do saber. Para Certeau (2014), toda instituição histórica guarda um lugar em branco, escondido de uma análise entre seus sujeitos, e revela a constituição de saberes eclesiásticos, eruditos, populares, de assuntos públicos, científicos e religiosos presentes nos objetos de consumo (materiais escolares).

É preciso mencionar que a criação do Sistema Educativo Radiofônico de Bragança ${ }^{1}$ e suas redes de escolas radiofônicas, segundo o Livro de Tombo ${ }^{2}$ (1971-1979), foi projetada devido à ausência de políticas públicas para o meio rural (no que tange à comunicação, ao transporte, à assistência socioeconômica, religiosa e cultural), dos principais elementos da higiene, de melhores condições de moradia, de um controle da natalidade e por conta, também, do aumento da prostituição e da ausência da alfabetização e escolarização. Tudo isso levou os Padres a desenvolverem um ensino para o camponês de Bragança ${ }^{3}$, ensino pensado para os jovens e adultos do interior num habitat de ignorância, vistos como incivilizados. Essa realidade esteve presente, na década de 1960 a 1970, em todo território paraense e, até mesmo, no meio rural de algumas regiões do Brasil.

Nesse ínterim, a abordagem da nova história cultural é sustentada neste estudo enquanto campo teórico e metodológico que privilegia a análise dos dados sobre as representações dos materiais escolares, que perpassam sobre as "práticas culturais, seus sujeitos e seus produtos, estes últimos se configuram em sua materialidade como objetos culturais" (NUNES; CARVALHO, 2005, p. 41) que foram produzidos, circularam e obtiveram uma apropriação no interior dos sistemas educativos radiofônicos e as escolas radiofônicas de Bragança, no Estado do Pará.

1 O Sistema Educativo Radiofônico de Bragança e sua rede de escolas radiofônicas foi implantado no dia 17 de setembro de 1960 por Padre Giambelli e D. Eliseu, ambos diretores e coordenadores do sistema. Eles formaram a primeira equipe Central, composta por professores-locutores e técnicos, enquanto que nas redes de escolas radiofônicas foram selecionados os monitores, sujeitos com habilidades de leitura e escrita para escutar o rádio e orientar os alunos sobre as atividades nas salas de aula em suas comunidades e paróquias do Município de Bragança (LIVRO DE TOMBO, 1971- 1979).

2 Os Livros de Tombo foram os materiais localizados no Arquivo do Tribunal de Contas da Diocese do Município de Bragança-Pará.

3 Conforme o Livro de Tombo (1971-1979), Bragança faz parte de um dos municípios do interior do Pará, constituído no Nordeste Paraense, e está localizado a 210 km de Belém, capital do Estado do Pará. 


\section{Cultura material escolar nas salas de aula das escolas radiofônicas: entre permanências e inovações pedagógicas}

As escolas radiofônicas situadas nas comunidades que compõem o município de Bragança foram construídas e concebidas nos mais diferentes espaços escolares. De acordo com o documento do MEB (DOCUMENTOS LEGAIS - APOSTILA 1/SÈRIE A - FUNDO MEB ${ }^{4}$, ACERVO CEDIC):

[...] A escola deverá funcionar em horário inteiramente adequado às populações a serem atingidas pelo Sistema de Escolas Radiofônicas. Para instalação de uma escola radiofônica poder-se-á aproveitar a sala do "grupo escolar", a sala da "casa paroquial", "a casa da fazenda" e até mesmo a casa dos moradores da localidade. Nela deverá haver, para o funcionamento das aulas, os seguintes materiais: - mesas ou carteiras; cadeiras ou bancos; um quadro-negro; giz e apagador; um aparelho de rádio cativo; lampiões quando não houver luz elétrica [...] (1961-1965, p. 27).

A adequação de horários das escolas radiofônicas tinha por finalidade atender às especificidades das populações que participavam dos Sistemas Educativos Radiofônicos nos mais variados espaços escolares das regiões brasileiras. Desse modo, cada escola radiofônica possuía normas e práticas específicas a serem ensinadas para os jovens e adultos. Sobre normas e práticas, Julia (2001) anuncia que o conjunto de normas que definem conhecimentos a ensinar e condutas a inculcar e um conjunto de práticas que permitem a transmissão desses conhecimentos e a incorporação de comportamentos constituem a cultura escolar. Logo, normas e práticas são coordenadas como dispositivos pedagógicos e podem variar em cada época.

Assim, os espaços escolares possuem características próprias, engajadas em contextos específicos, que produzem cultura material escolar nos mais variados contextos históricos, como anunciam Silva, Souza e Castro (2018).

4 A criação do Movimento de Educação de Base (MEB) ocorreu pela assinatura do Decreto $\mathrm{n}^{\circ}$ 50.370, baixado pelo presidente Jânio Quadros, que cria o Movimento de Educação de Base, a partir de 1960 num regime de convênio com órgãos federais e estaduais, com a Conferência Nacional dos Bispos do Brasil (CNBB), o Ministério da Educação e Ministérios de Obras Públicas, (DOCUMENTOS LEGAIS - APOSTILA 1/SÈRIE A - FUNDO MEB, ACERVO CEDIC; 1961 - 1965, p. 37). 
As relações orientadas pelo Movimento de Educação de Base (MEB), conforme Coimbra $(2003)^{5}$, sobre os materiais escolares para as escolas radiofônicas, de certa maneira, foram usadas, conforme as orientações deste programa educativo, tais como: mesas ou carteiras; cadeiras ou bancos; um quadro-negro; giz e apagador; um aparelho de rádio cativo; lampiões quando não houver luz elétrica e nos mais variados espaços: "grupo escolar", a sala da "casa paroquial", "a casa da fazenda" e, até mesmo, a casa dos moradores da localidade. Tanto os materiais quanto os espaços foram planejados para a alfabetização e a escolarização dos jovens e adultos. Sobre isso, Vidal (2009) argumenta que a escola pode transmitir a cultura dos signos da reprodução da sociedade como uma permanência pedagógica criada para manter o status quo e/ou promover uma cultura específica (de inovações pedagógicas) por meio das práticas culturais constituídas pelos sujeitos com os materiais escolares. De certa forma, quer sejam pelas permanências e/ou pelas inovações pedagógicas, a problematização sobre a transmissão da cultura na escola permite compreender os espaços escolares e os usos dos materiais escolares no interior das salas de aulas.

As três cenografias a seguir são representações dos espaços escolares e dos materiais escolares que apresentam as culturas dos jovens e adultos do município de Bragança na forma de significações e sentidos, constituidoras no cerne das escolas radiofônicas. Conforme Souza (2007), a funcionalidade da escola e a compreensão dos materiais escolares estão envolvidas pela identificação dos mobiliários, os acessórios, a infraestrutura do espaço escolar, os utensílios utilizados como os materiais de leitura e escrita, os mapas, os globos e as atividades humanas dos sujeitos com os materiais escolares.

Uma das cenografias foi localizada em uma casa particular de monitores, a segunda, em uma escola do município e a última, num barracão de palha. Foi possível identificar o funcionamento dos três espaços escolares das escolas radiofônicas de Bragança. Elas apresentam algumas permanências e inovações na sua organização e estão constituídas à luz da cultura material escolar com a presença dos mais variados materiais escolares no interior das salas de aula. A seguir, apresentamos o primeiro espaço escolar no cerne das escolas radiofônicas:

5 Em Bragança e no Amazonas, o Padre Aloísio da Silva Neno foi o principal responsável por coordenar o Movimento de Educação de Base. O MEB do Pará acompanhou a criação do MEB/ Nacional, visto que 'nasceu' dentro da CNBB por meio do incentivo de Dom Eugênio Sales, Dom Helder Câmara e Dom José Távora. Após a consolidação desse movimento, o MEB do Pará passou a obter o material de alfabetização para que os camponeses viessem a ler e escrever. 
FIGURA 1 - ESCOLA RADIOFÔNICA NA RESIDÊNCIA DA MONITORA

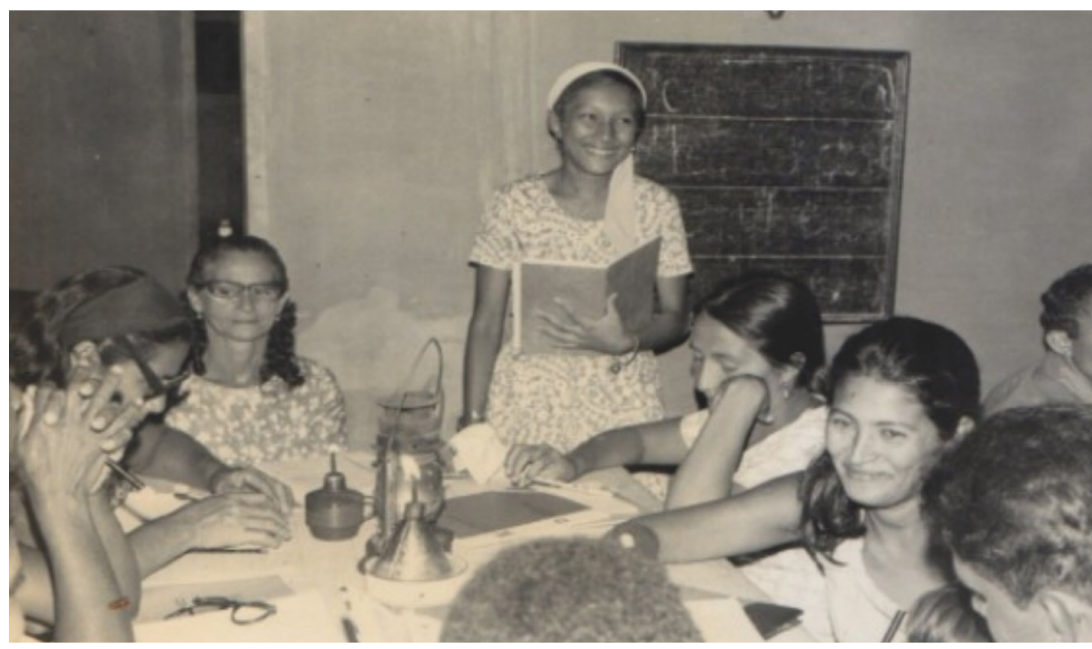

FONTE: Livro de Tombo - Figuras Diversas (1968 - 1975).

Na Figura 1, identificamos no espaço escolar um grupo de alunos sob a orientação de uma monitora que tinha um livro em suas mãos para reproduzir as atividades durante as aulas. Para Escolano (2012), as práticas culturais dos sujeitos podem ser vistas como ato de criação, codificação e transmissão cultural para os alunos que se desdobram em uma cultura específica, empírica, na escola.

É preciso compreender ainda que os ambientes escolares das salas de aula, no decorrer do século XX, e a composição do material escolar, conforme Souza (2007), buscavam uma racionalização da escola por meio de modos de organização e ensino mais produtivos e eficientes. As aulas, por exemplo, deveriam estar acompanhadas de valores de motivação e ser atrativas para acompanhar a educação mais moderna. Conforme Escolano (2012), as escolas 'nascem', se organizam e 'sofrem' transformações a partir do ato de operação cultural dos sujeitos escolares nos mais variados contextos sócio-históricos em que ela se coabita e interage. Dessa forma, as escolas radiofônicas apresentam algumas permanências daquilo que era prescrito pelo MEB/Nacional e pelos Coordenadores do MEB/SERB e inovações pedagógicas que são constituidoras de uma memória cultural na história das escolas radiofônicas para os jovens e adultos no Estado do Pará.

Além dos coordenadores das escolas radiofônicas de Bragança, existiam os monitores que geralmente eram escolhidos por serem da igreja católica, terem habilidades de leitura e escrita e serem uma das principais lideranças encontra- 
das na comunidade. Eles efetuavam e organizavam as matrículas dos alunos, mapeavam suas frequências, sistematizavam planos de aula e elaboravam os boletins, além de construírem relatórios para serem entregues aos supervisores do Sistema Educativo Radiofônico de Bragança (SERB), conforme aponta o Livro de Tombo (1971-1979).

A escola radiofônica da Figura 1 funcionava em uma casa particular geralmente cedida pelos próprios monitores onde, na parte de trás das residências ou nas salas, aconteciam as aulas. Nesse espaço, observamos sete alunos em uma mesa e um aluno em outra mesa, alguns estão olhando para suas atividades e outros olhando um para o outro; na parte de cima da mesa, identificamos cadernos e folhas de papel soltas com pauta e sem pauta para o desenvolvimento da escrita dos alunos. Como afirma Vidal (2009), na organização das salas de aulas, identificamos a permanência dos mais variados suportes de escrita (como: papéis, quadros negros e cadernos) e estes apresentam a compreensão sobre a cultura e escola, manifestada nas marcas da cultura material escolar.

A estrutura da sala de aula era constituída de alvenaria, tinha portas de madeira e era dividida em duas partes. Além disso, na parede dessa escola radiofônica, existe a fixação de um quadro negro que tem diferentes escritas, rabiscos no formato de letras, sílabas e vogais. No quadro, a monitora dividiu quatro linhas que organizam a dimensão espacial na horizontal, o que a auxiliava a não desviar a direção da escrita no espaço do quadro.

De certa forma, a organização das linhas no quadro também ajudava na escrita dos alunos em seus cadernos ou folhas de papel sem pauta, pois a maioria deles não tinha domínio pleno da escrita e, por serem trabalhadores camponeses, tinham inúmeras dificuldades para utilizar o lápis, situar a escrita no espaço das folhas e cadernos e registrar suas atividades. Assim, há um impedimento do aluno relacionar a escrita alinhada do quadro para as folhas de papel sem pauta e cadernos, o que podemos evidenciar com as marcas de uma escrita topográfica, onde a descrição do lugar da escrita está eminentemente relacionada ao espaço, à forma, aos cadernos e às folhas.

Assim, os materiais escolares em análise estão para além de uma natureza prescritiva, normativa e limitada em seu uso para o ensino e aprendizagem, pois compartilha-se com o anunciado de Souza (2007) $)^{6}$, segundo o qual o mundo dos objetos nas cenas das escolas deve ser analisado como um componente de

6 Durante muito tempo, o termo "materiais escolares" ficou restrito à natureza prescritiva de materiais didáticos, materiais auxiliares, numa ênfase entre metodologia e o método de ensino em que a didática restringiu o termo sobre a análise em que professores e alunos os utilizavam apenas para o ensino-aprendizagem. 
interpretação histórica destinada ao estudo das representações e das práticas culturais dos sujeitos escolares.

Na maioria das escolas radiofônicas, não existia energia elétrica, visto que esta era a realidade principalmente daquelas que funcionavam em barracões, mas também das casas particulares dos monitores. Por isso, identificamos a presença de duas lamparinas e um lampião acima da mesa. Conforme Assis (2011), as lamparinas eram materiais utilizados para iluminar as salas de aula, geralmente utilizava-se álcool para o funcionamento do lampião e querosene para o funcionamento das lamparinas. O lampião era outro material utilizado pelos monitores, pois sua principal finalidade era conduzir os alunos de suas residências até as escolas radiofônicas e de lá, às suas casas. Alguns alunos tinham seus próprios lampiões. O lampião usado nas escolas radiofônicas servia para clarear o espaço escolar juntamente com as lamparinas de pressão no centro da mesa.

Os lampiões eram do tipo aladins e, em sua estrutura, apresentavam características específicas para o seu manuseio, pois possuíam um depósito de querosene na base e uma bomba manual que, ao ser pressionada, introduzia ar no reservatório e impulsionava o querosene via um pequeno orifício até a camisa, que deveria estar previamente acesa com fogo. "A camisa ficava incandescente, produzindo uma luz clara e intensa. Por ser feita de um material delicado, era necessário manuseá-la com cuidado para não rasgar, tornando necessária à sua substituição [...]" (ALVES, 2016, p. 106).

Vale mencionar ainda que os lampiões, utilizados no interior das escolas radiofônicas, segundo Assis (2011, p. 116), eram "da marca alemã Petromax. Produzidos no final da década de 40 já não eram mais comercializadas na década de 60 , embora fossem usados com bastante frequência naquele contexto, uma vez que sua luz forte podia iluminar ambientes maiores". Assim esses lampiões eram utilizados na maioria das salas de aulas das escolas radiofônicas do Brasil.

Tanto os lampiões quanto as lamparinas serviam para suprir as instalações precárias no interior das salas de aulas. Nosso entendimento é que eles são dois materiais de iluminação que também faziam parte da organização e funcionamento das escolas radiofônicas de Bragança. A seguir, visualiza-se, na Figura 2, outros materiais escolares situados em uma escola radiofônica em Bragança (PA). 
FIGURA 2 - ALUNOS DE ESCOLA RADIOFÔNICA EM ESCOLA MUNICIPAL COM O RÁDIO CATIVO?

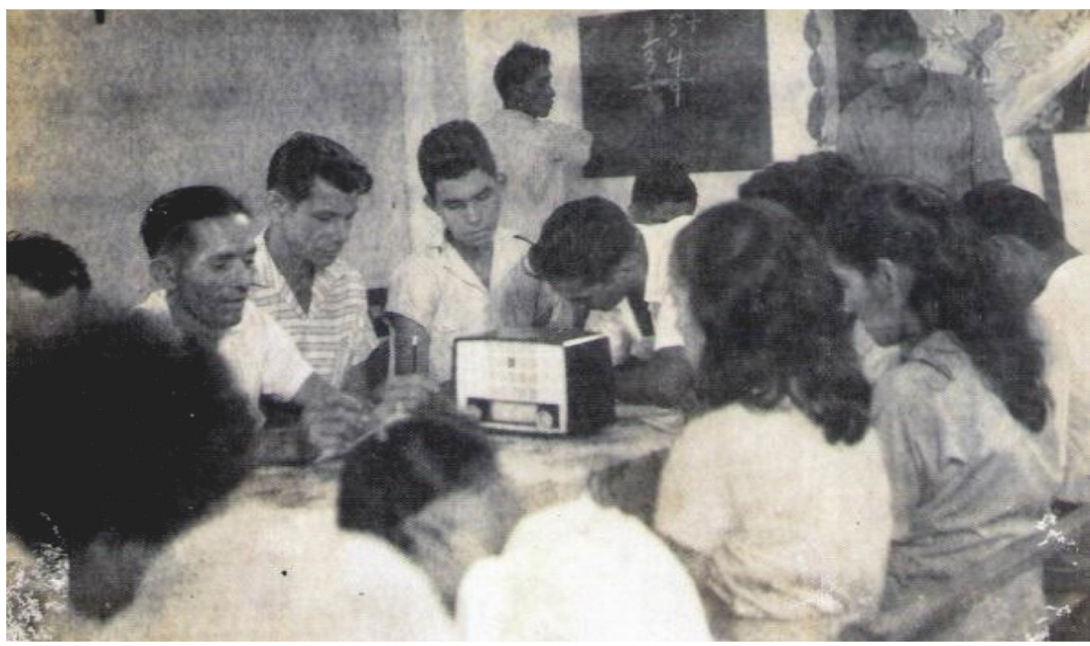

FONTE: Livro de Tombo - Figuras Diversas (1968 - 1975).

Nos dois grupos de alunos na sala de aula, os alunos estão distribuídos em círculos de culturas e estão ouvindo o rádio cativo. Observamos que há um acostamento de madeira boleado no banco para que as mulheres e homens pudessem apoiar suas costas. Na Figura 2, o receptor cativo e os círculos de cultura, concepções formuladas por Paulo Freire $(1991)^{8}$, são as principais inovações pedagógicas porque eles permitem que os alunos possam se concentrar na medida da escuta do rádio no centro da mesa.

De certa forma, o rádio cativo é um objeto que está articulado à escola como um dos progressos tecnológicos no processo de escolarização de jovens e adultos. Conforme Silva, Souza e Castro (2018), no século XX, grande parte dos objetos se materializou nas escolas pelos progressos tecnológicos, elementos

7 O rádio cativo foi fabricado pela Philips e era chamado de cativo porque foi construído para a escuta de uma única emissora. A ideia era projetar um rádio apenas para escutar as mensagens do evangelho no sentido de alfabetizar os jovens e adultos pelo Sistema Educativo Radiofônico de Bragança, conforme aponta o livro de tombo (1971-1979).

8 Os círculos de culturas iniciaram-se na década de 1960, com as primeiras práticas culturais desenvolvidas pelo educador Paulo Freire nas experiências do Movimento de Cultura Popular com a Alfabetização dos lavradores do Rio Grande do Norte e Recife, no Nordeste Brasileiro. A ideia de organizar a distribuição dos alunos em círculo de cultura propõe uma aprendizagem em que os alunos com os professores devem debater sobre as questões e os problemas de seu cotidiano e, por isso, há uma aprendizagem integral e horizontal na forma de aprender entre o educador e educando. 
importantes que estabeleceram um vínculo nada desprezível entre a escola, a indústria e a inovação tecnológica.

Estamos cientes de que os métodos de ensino na história da educação também estão relacionados às inúmeras mobílias confeccionadas para as instituições educativas. Como identificamos em alguns exemplos citados por Vidal (2009):

[...] existiram mobílias de banco e banca que foram utilizados para o agrupamento das crianças na relação do mesmo estágio de conhecimento; a orientação de um professor- monitor que auxiliava as crianças para repetir a lição inúmeras vezes, este método era orientado pelo ensino mútuo ou método Lancaster, durante as décadas iniciais dos Oitocentos e foram os principais causadores da miopia e da escoliose entre os escolares, devido as diferentes alturas entre banco e banca, segundo os médicos higienistas. Posteriormente surgiram outros modelos de mobília como [...] as carteiras de modelo individual com um ou dois lugares, estas eram fixadas com pé de ferro fundido para evitar o deslocamento do aluno no espaço escolar. $\mathrm{O}$ aluno, ainda, deveria retratar a observação do concreto para a formulação do pensamento abstrato mediado pelo ensino intuitivo e quando os alunos eram dirigidos diretamente pelo professor, abolindo a figura do monitor, e as classes eram formadas por estudantes do mesmo nível e deveriam ter os mesmos ritmos de aprendizagens, nestes foram também incorporados o método simultâneo[...]. A partir de 1920 foram surgindo outras mobílias "[...] cadeiras separadas de mesas que permitiam novas combinações do espaço escolar, está se deu concomitante ao ideário da escola ativa onde o aluno ao ser orientado pelo professor passava a construir sua própria aprendizagem pela experiência vivida [...] (p. 33-34).

Diana Vidal (2009) apresenta essas relações em diferentes tempos históricos para apresentar ao leitor os diferentes métodos de ensino para crianças com o uso da mobília. De certa forma, isto nos deu base para investigar e compreender que a partir das mobílias e distribuição dos alunos no interior das salas de aula das escolas radiofônicas, o método de ensino para os jovens e adultos das escolas radiofônicas de Bragança está constituído pelos círculos de cultura. A proposta apresentada pelo método de alfabetização de Paulo Freire (1991) é uma inovação pedagógica, na qual educador e educando mantêm uma relação horizontal na aprendizagem e não hierárquica como se foi e é pensada no interior das instituições educativas. Sobre o suporte de escrita do quadro negro (Figura 2), o monitor estava registrando o conhecimento matemático, especificamente uma conta de aritmética de dois números para que os alunos, ao 
terminarem de ouvir a aula pelo rádio, pudessem lembrar a operação transmitida pelos professores-locutores.

Neste sentido, o espaço da sala de aula presente também na casa do monitor, apresentava, entre outros desafios, o que se refere à posição do rádio cativo, pois era necessário utilizar o conhecimento advindo das orientações dos técnicos do Sistema Educativo Radiofônico de Bragança e padres para escolher uma direção no interior da sala de aula. $\mathrm{O}$ rádio cativo poderia ter mais qualidade na frequência, resultando na qualidade sonora e aprendizagem aos alunos. As normas informadas pelos técnicos para o posicionamento do rádio na sala de aula compõem as práticas escolares do monitor no ato de operacionalizar este objeto cultural. Sobre práticas, Julia (2001) afirma que elas estão imersas nos objetivos que presidem o ensino nas salas de aula, pois, quando os sujeitos se apropriam dos dispositivos pedagógicos, a partir das normas ditadas pelos programas oficiais, surgem práticas e normas que renovam cada programa pedagógico de ensino. Na última cenografia no interior da escola radiofônica, identifica-se o espaço escolar peculiar com seus respectivos materiais escolares:

\section{FIGURA 3 - ESCOLA RADIOFÔNICA EM UM BARRACÃO DE PALHA}

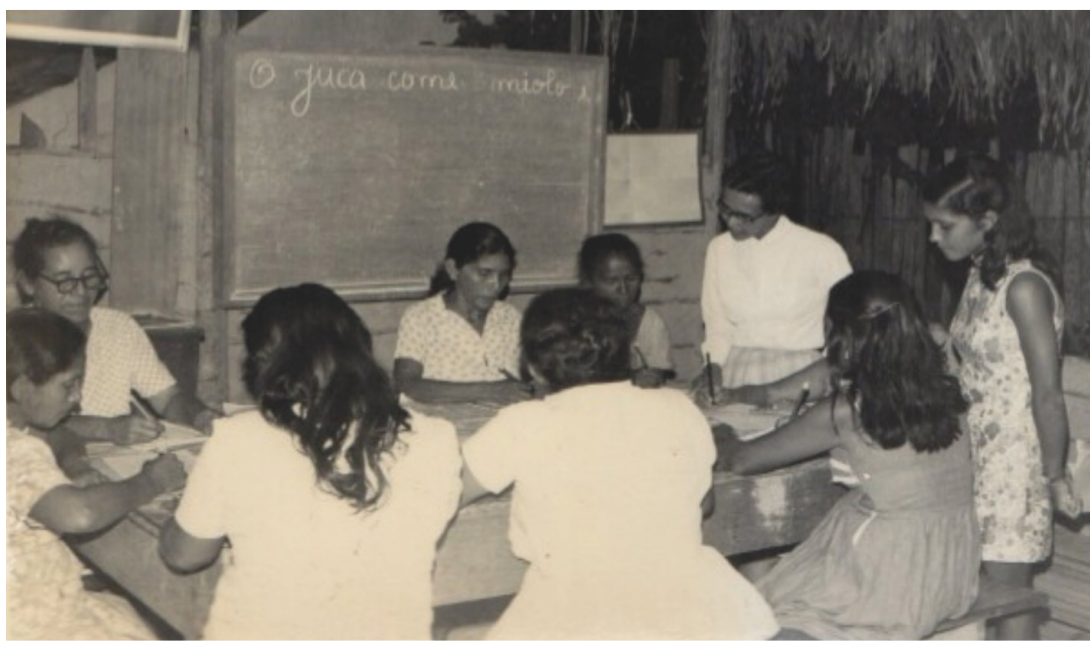

FONTE: Livro de Tombo - Figuras Diversas (1968- 1975).

A Figura 3 apresenta a estrutura da escola radiofônica em uma casa de madeira na forma de um barracão que tinha um telhado confeccionado de palha. As comunidades construíam muitas escolas radiofônicas em barracões com folhas secas que substituíam os telhados de barro, pois esses materiais eram mais 
acessíveis na floresta e de menor custo para os jovens e adultos ${ }^{9}$ do interior. As folhas de Inajá e Babaçu eram os principais materiais coletados nos mais variados municípios para a construção dos barracões das escolas radiofônicas de Bragança.

A palha de Inajá é engrossada e provém de uma palmeira que é plantada, em sua maioria, nas proximidades dos roçados das comunidades. Quando a folha de Inajá está jovem, o olho e o grelo são consumidos para a confecção de $\operatorname{cofos}^{10}$ para acondicionamento e transporte de camarão, caranguejo e siri. Quando a folha está madura, ela é utilizada para cobertura de paredes de casas, conforme apontam Oliveira, Potiguara e Lobato (2006). Observamos que as palhas de Inajá, utilizadas nas escolas radiofônicas, eram maduras, resistentes e consumidas também para outras finalidades pelas populações tradicionais de Bragança.

A palha de Babaçu advém de um tipo de palmeira presente no Estado do Pará e seu uso é bastante difundido na Amazônia, na Mata Atlântica, no Cerrado e na Caatinga. Por ter folhas largas, ela precisa ser coletada e deve ser aberta e exposta ao sol para murchar durante um período de 10 a 15 dias, tornando-se uma palha resistente. Além disso, o entrançamento das palhas é tão resistente que serve para a construção telhados de casa de madeiras, segundo Carrazzi, Cruz e Silva (2012). A maioria das escolas radiofônicas tinha este tipo de palha advinda da palmeira chamada Coco de Babaçu, as quais são encontradas em maior número na região territorial de Bragança.

É preciso destacar o consumo das palhas das palmeiras de Inajá e Babaçu, utilizadas como telhados para as casas de barracões, porque elas remontam a produção dos saberes geracionais dos indígenas que foram mesclados com a cultura dos caboclos da Amazônia Paraense no século XX. Esses saberes utilizados com esses materiais resistentes, além de contribuírem para a construção das moradias das populações tradicionais, evitavam a infiltração de água dentro da sala de aula, protegendo, assim, os alunos, monitores, materiais escolares e o receptor cativo (rádio) durante as inúmeras chuvas nas mais variadas escolas radiofônicas das comunidades.

As casas de palha são parte de uma cultura específica das populações do estado do Pará e retratam um tipo de escola. Sobre o tipo de escola, Castro

9 Os sujeitos pertencentes às escolas radiofônicas de Bragança eram jovens e adultos pescadores artesanais e ribeirinhos, comerciantes, colonos, camponeses, domésticas, alguns líderes de comunidades, intelectuais da tradição que tinham saberes específicos sobre a natureza e defendiam sua manutenção no âmbito da preservação por meio da utilização das palhas, artesanatos, dentre outros objetos regionais (Livro de Tombo 1971- 1979).

10 Materiais utilizados, também, pelos agricultores camponeses para transportar feijão e mandioca. 
$(2011)^{11}$ afirma que só temos uma dimensão da cultura material escolar sobre o funcionamento da escola quando evidenciamos os aspectos regionais: o tipo de escola, os materiais de escrita e leitura, o lugar de produção do espaço escolar e os recursos naturais, confeccionados nos cotidianos escolares.

No cerne, nas laterais e a frente do barracão da escola não havia paredes fechadas, eram estruturadas de barro e "pau a pique" para a sustentação da escola radiofônica. Nos fundos do barracão havia fixação de alguns utensílios como o quadro negro, onde estava escrito "O Juca come miolo", e um cartaz de cor branca fixado ao lado do quadro negro, objetos que permitiam o desenvolvimento das tarefas de escrita e leitura durante as aulas. Outro ponto fundamental é que ao lado esquerdo do quadro negro existia uma mesa para o monitor organizar o seu material (como: giz, textos, livros), construir relatórios e escolher o posicionamento do receptor cativo para a escuta durante as aulas.

Observamos no interior da sala de aula oito alunas, sete sentadas e uma em pé, além de uma irmã/supervisora do Comitê Central do SERB. As irmãs/ supervisoras iam visitar os rádios postos para auxiliar os monitores e alunos, bem como fiscalizar as atividades no interior das escolas. Segundo o Livro de Tombo (1971-1979), as irmãs supervisoras eram escolhidas pelos padres coordenadores do Sistema Educativo Radiofônico de Bragança (SERB) e participavam de diversos cursos de alfabetização e escolarização promovidos pelo MEB/Nacional e o MEB/Estadual.

Ao trazer algumas marcas específicas dos espaços das escolas radiofônicas, encontramos ainda algumas similitudes nas indumentárias dos jovens e adultos: as mulheres vestidas com roupas de algodão e chita florida e os rapazes e homens com roupa de algodão, ambos camponeses da Amazônia. As famílias camponesas do Estado do Pará eram constituídas por trabalhadores que tiravam seus sustentos das vendas de farinha, do pescado, da venda de gomas de tapioca, das artes culinárias, de práticas do artesanato e de produtos para serem vendidos ao comércio - beijus, pimenta do reino, feijão, etc.

$\mathrm{O}$ uso das indumentárias dos jovens e adultos das escolas radiofônicas de Bragança pode ser visto como o uso de uniformes escolares que se diferenciam da composição dos que são utilizados no cotidiano cultural de outras escolas, isso porque, conforme Ribeiro e Silva ${ }^{12}$ (2012), o uniforme escolar é concebido como um dos elementos da cultura material escolar e apresenta uma regra im-

11 Temos o discernimento de que o autor utiliza os recursos naturais para explicar os materiais adotados nas escolas do Maranhão, nos Oitocentos, contudo, tomamos como empréstimos seus conceitos porque eles se aproximam do estudo em voga, que trata sobre a utilização dos recursos naturais utilizados para o funcionamento das escolas.

12 Temos ciência de que as autoras efetuam seus estudos sobre o uniforme escolar na história da educação catarinense no século XX. 
posta no regimento das instituições de ensino como parte da disciplina escolar para os sujeitos escolares.

Nas instituições escolares, os uniformes constituem-se enquanto um artefato que normatiza as condutas dos corpos dos sujeitos escolares. Eles postulam uma educação igual para todos com base na homogeneização dos sujeitos, ou seja, carrega significados e identifica posições nas mais variadas escolas públicas brasileiras que descaracterizam as diferenças e/ou, dependendo do contexto histórico, pode servir de punição contra todo ato de transgressão no cotidiano escolar, como defendem Ribeiro e Silva (2012).

Com relação à utilização dos cadernos, folhas e lápis preto e branco com borracha para os alunos registrarem as lições de alfabetização e escolarização, destacamos essa ação entre os sujeitos e o próprio material prescrito/advindo do Movimento de Educação de Base Nacional. Esses materiais de suportes e de escrita apareceram em constante no interior das salas de aula das três imagens interpretadas e constituem as permanências pedagógicas.

Sobre as permanências nas três figuras, há uma distribuição dos alunos nas escolas radiofônicas: os alunos estão sentados em bancos de madeira (toscos) e apoiando seus braços nas mesas de madeira cobertas com algumas toalhas artesanais. É evidente que a ausência de um assento que firmasse as costas dos alunos prejudicava sua saúde, pois eles já chegavam exauridos nas escolas devido às suas atividades nos campos, no comércio e nos domicílios durante o dia. Logo, no período da noite não tinham como encostar a coluna. De certa forma, entre a altura dos bancos e mesas, alguns alunos levavam seu rosto até perto das folhas e outros traziam as folhas para próximo de sua visão por apresentarem problemas de vista.

Os bancos e mesas quando não eram fabricados apenas na sede central do Município de Bragança, segundo o livro de tombo (1971-1979), eram produzidos, na maioria das vezes, pelos marceneiros das próprias comunidades. Alguns extraíam as madeiras da floresta para a confecção dos bancos e mesas, pois grande parte dos barracões não tinha mobília específica para as aulas da Educação de Jovens e Adultos. Nas salas de aula, onde as escolas radiofônicas funcionavam cedidas pelas escolas do Município, as mobílias construídas pelos marceneiros fazem parte de uma inovação pedagógica, cultura específica dos paraenses.

Assim, os bancos e as mesas retangulares nos remetem a analisar a forma de organização da sala de aula. A distribuição dos alunos com as mobílias perpassa também aos círculos de culturas propostos pelos programas educativos de alfabetização de Paulo Freire (1991), dos quais o MEB se apropriou para desenvolver nas escolas radiofônicas como um dos métodos de ensino.

Um fator importante da aproximação dos círculos de cultura se deve também porque muitas localidades do interior do Estado do Pará, nos anos de 1960, 
foram se organizando em pequenas vilas, colônias e povoados com famílias, onde a maioria das escolas funcionava com as turmas de Educação de Jovens e Adultos (EJA), desenvolvendo o espírito comunitário por meio das equipes de serviços que integralizavam as ações educativas e sociais nas comunidades.

De certa forma, essa forma de organização, com as mobílias no formato de círculos nas escolas radiofônicas, rompe com o que Bourdieu (2010) menciona sobre o funcionamento da escola, que foi projetada enquanto um sistema de ensino relacionado aos diferentes grupos sociais que têm bens culturais e simbólicos e produzem habitus que geram um sistema de significações hierarquizadas e, de certa maneira, acirram as desigualdades sociais.

Tal hierarquização está constituída pelas estruturas sociais e reproduz e conserva o capital cultural, conforme Bourdieu $(2010)^{13}$, da cultura dominante e elitizada no interior da escola. As classes populares que tiveram pouco acesso ao capital cultural, bens de consumo da sociedade, não se encontram e se identificam com os bens simbólicos desenvolvidos no interior da escola, tendendo ao fracasso escolar. Para Julia ${ }^{14}$ (2001), a hierarquização nos espaços escolares não pode ser estudada sem a análise precisa das relações conflituosas ou pacíficas que ela mantém, a cada período de sua história, com o conjunto das culturas escolares que lhe são contemporâneas, como, por exemplo, a cultura dominante, cultura religiosa e/ou a cultura popular.

Logo, a formação de classes escolares faz jus ao seu nome não apenas na formação de uma turma em que o professor ensina e o aluno aprende, mas na prática cultural do professor, o qual produz a diferenciação de classes sociais no interior da sala de aula de forma consciente ou inconsciente. Para Bourdieu (2010), a escola está imersa ao capital cultural e habitus que produz uma luta simbólica e significações entre os sujeitos professores e alunos, bem como a utilização dos materiais de ensino como os livros didáticos, por exemplo.

A sala de aula reproduz a relação de dominação cultural de um sistema que legitima uma única cultura, a cultura dos dominantes que têm códigos linguísticos da burguesia, vistos como universais e únicos na forma de capital cultural. Assim, ela se distancia de ser libertadora como propunha Freire (1991), e se torna reprodutora, conservadora num jogo de dominação simbólica.

A própria distribuição das cadeiras enfileiradas enquanto um dispositivo de controle já demonstra isto, onde o professor é a figura central do ensino e

13 O capital cultural realiza uma operação e seleção dos bens simbólicos dos sujeitos e acaba promovendo ao mesmo tempo a segregação entre os que não têm o mesmo acesso aos bens simbólicos, o que promove uma escola que mantém a ordem vigente de uma hierarquia cultural dominante e conservadora sobre os agentes sociais das classes dominadas e populares.

14 Em pleno século XX, vemos uma escola com parâmetros técnicos e cívicos, fruto de uma burguesia que impõe uma pedagogia normativa. 
aqueles que não conseguem apreender os conhecimentos se sentem excluídos e, não mantêm o diálogo nem com o professor e nem com seus pares, alunos. Logo, reproduz-se um modelo de hierarquização.

Nas três figuras das escolas radiofônicas, as mobílias não estão organizadas em filas e voltadas para a mesma direção do quadro com um professor. Elas propiciavam aos alunosestar um de frente para o outro e suas principais aprendizagens eram com a escuta do rádio cativo e a orientação dos monitores, ou seja, os professores não estavam presentes no interior das escolas radiofônicas, apenas sua voz pelo rádio transmitia as mensagens aos alunos. Assim, ele não era a única figura central, pois o monitor estava escutando com os alunos as aulas e os orientava durante ou após as aulas. Isso demonstra uma cultura específica, de inovação pedagógica de um ensino produzido no interior das escolas radiofônicas do município de Bragança, Estado do Pará.

O MEB defendia uma representação de educação crítica e emancipatória no âmbito da alfabetização e escolarização de jovens e adultos com base na ideia de Paulo Freire (1991), em que, a partir das experiências de vida dos sujeitos, seu universo vocabular e o lugar social, presente no contexto dos alunos, passariam a ser decodificados pela aquisição da palavra escrita e compreensão do mundo. Por isso, ele defendia que a leitura de mundo antecede a leitura da palavra, pois, ao serem problematizadas, possibilitavam a conscientização e politização dos sujeitos do lugar em que se vive para promover a transformação da sociedade.

Freire (1991, p. 22) criticava a utilização dos métodos de alfabetização puramente mecânicos. Para ele, era preciso valorizar uma alfabetização "ligada realmente à democratização da cultura e que servisse de introdução; ou, melhor dizendo, uma experiência susceptível de tornar compatíveis suas existências de trabalhador". Assim, como prática de liberdade, dialoga com a cultura simbólica, cultura popular, dos sujeitos pertencentes a um determinado contexto. Por isso, ele aponta algumas fases metodológicas que orientam as práxis dos alfabetizadores:

a) "a descoberta do universo vocabular", a primeira fase dos grupos sociais com quem se trabalha, está relacionado ao sentido existencial do sujeito, das palavras, das experiências ligadas ao grupo;

b) "as escolhas das palavras" selecionadas dentro do universo vocabular pesquisado. Este se organiza por três critérios - b1) "o da riqueza silábica"; b2) "o das dificuldades fonéticas" onde deve-se a partir das dificuldades fonéticas da língua a fim de colocá-las na ordem crescente; b3) "o conteúdo prático da palavra" que constituísse no engajamento de maior compromisso possível da palavra numa realidade de fato, social, cultural, política; 
c) "a criação de situações existenciais" típicas do grupo com o qual se trabalha, esta desempenha o papel de "desafios" apresentados aos grupos, de situações problemáticas, codificadas, que levam em si elementos para que sejam decodificados pelos grupos com a colaboração do coordenador; d) a "elaboração de fichas indicadoras" que ajudam o acompanhamento dos coordenadores durante o seu trabalho;

e) a "leitura das fichas com a decomposição das famílias fonéticas" correspondentes às palavras geradoras (FREIRE, 1991, p. 23-24, grifos nossos).

O conjunto de cinco fases metodológicas do material elaborado, enquanto um dispositivo, pode(ria) ser desenvolvido no trabalho de alfabetização para as escolas radiofônicas do Brasil e propicia(ria) a reflexão sobre o conceito antropológico da cultura - que conduzirá os grupos a conscientizarem-se para alfabetizarem-se. Portanto, elas são as fases de elaboração e aplicação do método que surgem em meio às situações locais que abrem perspectivas para a análise de problemas regionais, nacionais e internacionais.

Os leitores devem se perguntar o porquê de trazermos essas fases metodológicas da alfabetização neste estudo? O que isso tem a ver com a cultura material escolar? É preciso mencionar que a apropriação de alfabetização desenvolvida por Paulo Freire (1991) e assumida pelo MEB para as escolas radiofônicas nos induziu a questionar: Quais as permanências identificadas nas escolas radiofônicas de Bragança em relação às orientações do MEB/Nacional? E que inovações pedagógicas se diferem em relação às orientações nacionais do MEB? Aqui se tem a clareza de que o MEB desenvolveu um programa educativo para alfabetizar e escolarizar os jovens e adultos do Brasil pelas representações de educação crítica e emancipatória, mas, nas escolas radiofônicas de Bragança, elas nos induzem a mencionar que as representações evangelizadoras foram as que mais se fizeram presentes neste estudo. Isso só foi possível de ser interpretado pela compreensão de natureza da cultura material escolar no SERB, presente nos materiais escolares utilizados no interior das salas de aula para a formação dos alunos.

Conforme visualizamos nos suportes de escrita do quadro negro, identificamos a letra "C" e "h" soltas e quase apagadas (Figura 1), e uma conta aritmética que apresenta o cálculo "de 15 mais 34", (Figura 2), além da frase "o Juca come miolo" (Figura 3). Na totalidade dessas informações, visualizamos uma construção de alfabetização imersa na utilização de sílabas e não de palavras advindas do vocabulário dos educandos; sobre o miolo que Juca come, há uma representação descontextualizada e que não leva em consideração as representações críticas, de questões-problema do contexto do aluno e o cálculo sem relacionar as práticas de trabalho do camponês paraense. Tudo isso nos faz entender que, apesar de serem desenvolvidas formações críticas pelos membros 
integrantes do Movimento de Educação de Base no período em tela (1960 a 1970), os professores-locutores acabavam por reproduzir um ensino mecânico e descontextualizado aos jovens e adultos nas escolas radiofônicas de Bragança. Isso se deve pelo motivo do contexto da ditadura militar que defendia o método mecânico e de repetição ou pela defesa dos Padres do Sistema Educativo Radiofônico que defendiam a representação de educação evangelizadora e/ou pela falta de compreensão dos sujeitos escolares sobre o método de alfabetização proposto pelo MEB. Nesse ínterim, as representações dos espaços escolares com o uso dos materiais escolares nos ajudaram a compreender a cultura material escolar existente no cerne das escolas radiofônicas de Bragança e, ainda, suas permanências e as inovações pedagógicas no Estado do Pará.

\section{Considerações finais}

A compreensão sobre a cultura material escolar no Sistema Educativo Radiofônico possibilitou reconstituir uma cultura específica radiofônica a partir dos diversos espaços e sujeitos escolares que atuaram no desenvolvimento de práticas culturais e apropriações com os materiais escolares para a alfabetização e escolarização dos jovens e adultos em Bragança (PA).

Sobre os tipos de escola, elas funcionavam em uma casa particular da monitora, nas escolas dos municípios ou em barracão de palhas. Para efetuar a compreensão de análises dos materiais escolares, foram utilizadas a natureza da cultura material no cerne dessa instituição, analisadas a partir de três fotografias.

As três primeiras fotografias trazem à cultura empírica constituída no interior das salas de aula. Na escola radiofônica que funcionava numa casa particular e era cedida pelos monitores, a estrutura da sala de aula era constituída de alvenaria, tinha portas de madeira e era dividida em duas partes. Além disso, foi constatada a presença de materiais escolares em cima da mesa, como: cadernos, folhas de papel com pauta e sem pauta para o desenvolvimento da escrita dos alunos e a fixação de um quadro negro que tem diferentes escritas e rabiscos no formato de letras, sílabas e vogais com divisões de linhas. Outros objetos interessantes foram os materiais de iluminação, os lampiões e as lamparinas que eram dispositivos utilizados nas salas de aula, visto que, na maioria das escolas radiofônicas, não se tinha energia elétrica.

$\mathrm{Na}$ segunda imagem, destacamos o uso do rádio cativo e os círculos de cultura, principais inovações pedagógicas porque eles permitem que os alunos pudessem se concentrar na escuta do rádio no centro da mesa. 
A terceira fotografia apresenta a estrutura da escola radiofônica em uma casa de madeira na forma de um barracão que tem um telhado confeccionado por palhas. Esta era uma identidade bastante presente nas escolas radiofônicas de Bragança, os barracões de palhas que as sustentavam.

Com relação à mobília das escolas, foi identificada uma permanência. Observa-se nas três figuras que há uma distribuição dos alunos que estão sentados em bancos de madeira (toscos) e apoiando seus braços nas mesas de madeira cobertas com algumas toalhas artesanais. Além disso, as três figuras indicaram algumas inovações no cerne das escolas radiofônicas, pois os alunos não estavam organizados em filas e voltados para a mesma direção do quadro com um professor; elas propiciavam a eles estarem um de frente para o outro e suas principais aprendizagens eram com a escuta do rádio cativo e a orientação dos monitores, pois o próprio docente não se encontrava no interior das escolas radiofônicas.

Sobre o método de ensino, só foi possível de ser compreendido pela natureza da cultura material escolar das mobílias, o quadro e os bancos. $\mathrm{O}$ ensino projetado pelo MEB/Nacional é de uma representação crítica emancipatória que possibilitava a conscientização e politização dos sujeitos do lugar em que se vive para promover a transformação da sociedade. Entretanto, ao se analisar os suportes de escrita, identificou-se que, no quadro negro, as letras "C" e "h" estão soltas e quase apagadas; a frase "o Juca come miolo" e uma conta de aritmética que apresenta o cálculo "de 15 mais 34" indicaram a construção de alfabetização e escolarização imersas na utilização de sílabas e não de palavras advindas do vocabulário do educandos; sobre o miolo que Juca come, há uma representação de evangelização/descontextualizada e que não leva em consideração as representações críticas de questões problemas do contexto do aluno, além do cálculo não relacionar as práticas de trabalho do camponês da Amazônia.

Portanto, as permanências e inovações pedagógicas só puderam ser identificadas a partir da principal chave de análise desse estudo, a cultura material escolar identificada: no uso dos materiais de escrita (giz e lápis com borracha); materiais de suporte de escrita (quadro negro; cartaz; cadernos e folhas de papel sem pauta); as mobílias (mesas de madeiras toscas e bancos retangulares de madeiras); materiais de leitura (pequenos textos e relatórios); materiais de iluminação (lamparinas de pressão e lampiões aladins); as indumentárias das mulheres e homens (roupas de chita artesanal e algodão); os materiais de proteção das escolas radiofônicas (palhas de Inajás e Babaçu) e o material de comunicação e ensino (intitulado como rádio cativo). Dessa forma, os materiais escolares eram imersos por representações críticas, emancipatórias e evangelizadoras cuja finalidade era alfabetizar os jovens e adultos nas salas de aula das escolas radiofônicas de Bragança, no Estado do Pará. 


\section{REFERÊNCIAS}

ALVES, Kelly Ludkiewicz. Entre as cartas e o rádio: a alfabetização das escolas do MEB em Pernambuco. 2016. Tese (Doutorado em Educação) - Pontifícia Universidade Católica de São Paulo, São Paulo, 2016.

ASSIS, Marcia Maria Alves de. Ensino de matemática pelo rádio (1950-1970): uma história falada e um documentário didático. 2011. Dissertação (Mestrado em Ensino de Ciências Naturais e Matemática) - Universidade Federal do Rio Grande do Norte, Natal, 2011.

BOURDIEU, Pierre. O poder simbólico. Tradução de Fernando Tomaz. 13. ed. Rio de Janeiro: Bertrand Brasil, 2010.

CARRAZZI, Luís Roberto; CRUZ, João Carlos; SILVA; Marcia Lima da. Manual tecnológico: aproveitamento integral do fruto e da palha do babaçu. 2. ed. Brasília: ISPN, 2012.

CASTRO, Cesar Augusto. A presença dos materiais escolares no Maranhão Oitocentista. In: CURY, Cláudia Engler (Org.). Objetos, práticas e sujeitos escolares no Norte e Nordeste. São Luis: EDUFMA; UFPB; Café \& Lápis, 2011. p. 13-34.

CERTEAU, Michel de. A invenção do cotidiano: 1. Artes de Fazer. Tradução de Ephraim Ferreira Alves. 22. ed. Petrópolis: Vozes, 2014.

COIMBRA, Oswaldo. A denúncia de Frei Betto: o drama de católicos perseguidos em 64 começa a vir à tona. In: COIMBRA, Oswaldo. Dom Alberto Ramos mandou prender seus padres: a denúncia de Frei Betto contra o Arcebispo do Pará, em 1964. Belém: Paka-Tatu, 2003. p.17- 22.

ESCOLANO, Augustin Benito. Las materialidades de la escuela (a modo de prefácio). In: GASPAR, Vera Lucia; PETRY, Marília Gabriela (Org.). Objetos da escola: espaços e lugares de uma cultura material escolar (Santa Catarina - séculos XIX e XX). Florianópolis: Insular, 2012. p. 11-18.

FREIRE, Paulo. Pedagogia do oprimido. 17. ed. Rio de Janeiro: Paz e Terra, 1991.

GASPAR DA SILVA, Vera; PETRY, Marilia Gabriela (Org.). Objetos da escola: espaços e lugares de constituição de cultura material escolar (Santa Catarina - séculos XIX e XX). Florianópolis: Insular, 2012.

JULIA, Dominique. A cultura escolar como objeto histórico. Tradução de Gizele de Souza. Revista Brasileira de História da Educação, Maringá, n. 1, p. 9-44, 2001. (Original francês mimeo, 1993).

LIVRO DE TOMBO. Prelazia do Guamá, 1971-1979. Bragança: Tribunal de Contas da Cúria da Diocese de Bragança, s.d. v. IV.

LIVRO DE TOMBO. Figuras diversas, 1968-1975. Bragança: Tribunal de Contas da Cúria da Diocese de Bragança, s.d. 
MOVIMENTO DE EDUCAÇÃO DE BASE - MEB/DOCUMENTOS LEGAIS-APOSTILA 1/SÉRIE A - FUNDO MEB. In: Acervo do Centro de Documentação Professor Casemiro dos Reis Filho (CEDIC - PUC - SP - 1961-1965). Disponível em: http:// www.pucsp.br/cedic/principais/quem_somos/historia.htm. Acesso em: 22 dez. 2018.

NUNES, Clarice; CARVALHO, Marta Maria Chagas de. Historiografia da educação e fontes. In: GONDRA, José Gonçalves (Org.). Pesquisa em história da educação no Brasil. Rio de Janeiro: DP\&A, 2005. p. 509-523.

OLIVEIRA, Jorge; POTIGUARA, Raimunda Conceição de Vilhena; LOBATO, Luiz Carlos Batista. Fibras vegetais utilizadas na pesca artesanal na microrregião do salgado, Pará. Boletim do Museu Emílio Goeldi-Ciências Humanas, Belém, v. 1, n. 2, p. 113-127, maio/ago. 2006.

RIBEIRO, Ivanir; SILVA, Vera Lucia Gaspar. Das materialidades da escola: o uniforme escolar. Educação e Pesquisa, São Paulo, v. 38, n. 3, p. 575-588, jul./set. 2012.

SILVA, Vera Lucia Gaspar da; SOUZA, Gizele de; CASTRO, Cesar Augusto. Por uma apresentação: a materialidade escolar entre caminhos, pesquisas e Diálogos. In: SILVA, Vera Lucia Gaspar da; SOUZA, Gizele de; CASTRO, Cesar Augusto (Org.). Cultura material escolar em perspectiva histórica: escritas e possibilidades. Vitória: EDUFES, 2018, p. 10-25.

SOUZA, Rosa de Fátima. História da cultura material escolar: um balanço inicial. In: BENCOSTA, Marcus Levy (Org.). Culturas escolares e práticas educativas: itinerários históricos. São Paulo: Cortez, 2007. p. 163- 187.

VIDAL, Diana Gonçalves. No interior da sala de aula. Ensaio sobre culturas e práticas escolares. Revista Currículo sem Fronteiras, Rio de Janeiro, v. 9, n. 1, p. 25-41, jan./ jun. 2009. 